\title{
U.S. Welfare Reform: What's Relevant for Europe?
}

\author{
Rebecca M. Blank ${ }^{*}$
}

\begin{abstract}
This paper reviews the U.S. welfare reform efforts over the 1990s and the effects of these reforms to date. Seven "lessons" of potential interest to European observers are discussed, with particular attention to the conclusions of more recent research. Such research indicates, for example, that more effective programs contain both positive and negative incentives, utilise work-first as well as job training programs, and provide some important supports beyond just job and work skills. The paper ends with some speculations about why European policy-makers are becoming more interested in U.S. welfare reform experiments than they have been in the past. (JEL I3, J2, H1)
\end{abstract}

\section{Introduction}

In the 1990s, the organisation of means-tested support for low income families changed dramatically in the United States, with reductions in the availability of cash or in-kind support for non-working families, substantial increases in support for working families, and the devolution of program decision-making from the federal to the state level. This change was driven in part by a desire to provide stronger work incentives for low-income single mothers and avoid "welfare dependence", typically defined as long-term use of public assistance. Other frequently-mentioned reasons behind these program changes included a desire to allow more state discretion and impose fewer federal mandates, and a desire to reduce rising rates of non-marital childbearing.

Such concerns have not historically been part of the conversation about social assistance programs in many European countries. In fact, U.S. welfare programs have frequently been viewed by Europeans as too limited and too punitive, resulting in unacceptably high U.S. poverty rates. It is therefore somewhat surprising that some European policymakers have been deeply interested in the lessons of U.S. welfare reform and have even tried to adapt recent U.S. reform efforts to their own societies. For instance, the UK has adopted the Working Families Tax Credit, modelled on the U.S. EITC program. The Netherlands has moved to privatise parts of their disability, public employment and social

* Address: University of Michigan, Gerald R. Ford School of Public Policy, 440 Lorch Hall, Ann Arbor, MI 48109-1220.

Prepared for the CESifo Area Conference on Employment and Social Protection, 14-15 June 2002. 
insurance administration to increase efficiency (Evans, 2001). Some German cities have even experimented with time-limited public assistance (Feist and Schöb, 1998)

In this paper, I discuss the potential relevance of U.S. welfare reform to European concerns. The first section briefly summarises the nature of the U.S. changes and their effects on behaviour and outcomes among the low income population. The second section discusses potential lessons of interest to European observers. The last section presents several hypotheses about why the European and U.S. conversations on public assistance program design moved closer to each other over the 1990s. Throughout this paper, when I refer to "Europe", I am referring to the western European nations with well-developed welfare states.

\section{U.S. welfare reform in the 1990s}

Because so many people have written summaries of U.S. welfare reform, I use this section to only briefly outline some of the key changes occurring in the U.S. during the past decade. ${ }^{1}$ Program changes occurred in two major areas, the design of cash assistance programs and the availability of work support programs. I discuss each in turn and then describe the rapid behavioural changes that occurred following these policy changes.

\subsection{Changes in cash assistance and related programs}

In 1996, the U.S. passed the Personal Responsibility and Work Opportunity Reconciliation Act (PRWORA). While controversial, the bill passed the Congress with a relatively high degree of bipartisan support. Among its major provisions were:

- Devolution of greater program authority to the states. PRWORA replaced the primary cash assistance program for low income families, Aid to Families with Dependent Children (AFDC), with a block grant, the Temporary Assistance for Needy Families (TANF) block grant. This removed most federal eligibility and payment rules, giving states much greater discretion in determining the eligibility rules and design of cash support programs.

1 For a detailed discussion of these changes see Blank (2002) or Blank and Ellwood (2001). 
- Changes in financing. The TANF block grant provides a fixed amount of federal money to the states. This is quite different from the matching grant provisions under AFDC in which federal funds moved up or down with state funding.

- Ongoing work requirements. By 2002, at least 50 percent of all families receiving TANF support were required to be working or in work preparation programs. States were given great discretion in designing and implementing such programs. The law treated caseload reductions as similar to work, however. Thus, a state which reduced its caseload by 60 percent would meet its work requirement regardless of how many current or former recipients were actually employed. Because all states experienced large caseload reductions, the pressure to meet work requirements was much reduced.

In addition to these changes, PRWORA also encouraged states to implement programs that would reduce out-of-wedlock child bearing; it limited eligibility to Food Stamps and Supplemental Security Income (the cash assistance program to low-income aged and disabled individuals); and it greatly restricted the access of legal immigrants to all forms of means-tested public assistance.

States were required to replace AFDC with their own TANF-funded plans for cash assistance within a year of PRWORA's passage. Virtually all states took advantage of their newly-granted discretion to make major changes in their welfare programs, but different states made very different choices. By the early 2000s, U.S. public assistance policies across states had become extremely diverse. Seven of the most important program elements that vary greatly across states are described here.

Benefit levels. States have always been able to choose their own benefit levels and in some ways this part of the system has changed the least. There always were substantial differences in dollars paid to low-income families across different states. The primary trend in benefit levels in the 1990s has been inflation erosion (a trend visible since the early 1970s). The median benefit level across the 50 states fell from USD 480/month for a family of three in 1990 to USD 379 in 2000, almost entirely due to inflation erosion (both numbers in 2000 dollars).

Earnings disregards. There were relatively limited and federally-determined earnings disregards in the old AFDC program. Most women saw their benefits taxed away at a similar (high) rate across states as they went to work. Many states developed TANF-funded programs with much higher earnings disregards, hoping to provide a greater incentive to work. The magnitude of this effect can be calculated by estimating how much a woman would receive in cash benefits if she went to work at USD 6.00/hour (slightly above the mini- 
mum wage) for 30 hours per week, with no additional income. Before the passage of PRWORA, this woman would have been ineligible for any cash assistance in half the states. By 2000 most states would have provided some support to this woman; in 28 states the support would have exceeded USD 1000 over the first two years of work. ${ }^{2}$

Welfare to work programs. States began to expand their welfare-to-work efforts in the early 1980s, but these efforts increased further after the passage of PRWORA. By 1999, 38.3 percent of the public assistance caseload was engaged in work or job activities. ${ }^{3}$ The exactly nature of these programs varies across states. Most states are focusing almost entirely on "work first", that is, getting recipients into a job as soon as possible without concern for additional job training or skill development. Programs focus on narrow job preparation skills (interviewing, organising child care, etc.) and job search assistance.

Sanctions. If expanded earnings disregards provide a positive incentive to go to work, sanctions provide the negative incentive. Sanction policies penalise individuals on public assistance who do not follow the rules, most commonly individuals who miss required job preparation or job search sessions. Sanctions vary in how much they reduce benefits and for how long. Pavetti and Bloom (2001) classify 25 states as "strict", including a number of states that impose permanent full benefit losses on families of noncompliant individuals. They classify 13 states as "lenient", imposing only temporary or partial reductions.

Time Limits. PRWORA enacted a 60 month time limit on how long individuals could utilise TANF-funded benefits. At their discretion, states can set shorter time limits or provide state funding beyond 60 months. Seventeen states have time limits of less than 60 months for some families, 26 states use the 60 month federal time limits and eight states have not imposed mandatory time limits on all benefits. For instance, several states impose time limits on adult recipients but continue benefits for children (Pavetti and Bloom, 2001).

Diversion. PRWORA ended the national entitlement to public assistance, hence states can now deny assistance to individuals deemed "work-ready". A number of states impose various screening devices to "divert" people from welfare. Some states impose work search requirements on applicants prior to allowing them onto welfare; others provide one-time cash assistance in lieu of ongoing public assistance.

Work Support Subsidies. States have recognised the need to help families with work-related expenses, especially child care subsidies. In 1996 state and federal governments together spent USD 32.4 billion on AFDC, with 76 percent

2 For more information on these calculations see Blank (2002).

3 U.S. Department of Health and Human Services (2000, Table 3:1). 
of that going into cash assistance. By 2000, total spending on TANF was USD 26.4 billion, with only 41 percent going into cash assistance (Weil, 2002). Big increases in child care, transportation assistance, and funding for work programs displaced cash support.

These changes dramatically reconfigured welfare programs in the United States by the early 2000s, with great variation across the states in their individual programs. In contrast to earlier years, where analysts could categorise states as more or less generous on the basis of their AFDC benefit levels, it is now very difficult to determine a linear ranking of state generosity. Some states with higher benefit levels have much stricter sanction policies. Some states with lower benefits have much higher earnings disregards. This makes it increasingly difficult to analyse welfare reform at a national level in the United States. By 2002, there was not one, but 50 welfare programs in the United States.

It should be clear, however, that virtually all of these changes increased the incentives to work. Work-requirements, sanctions, time limits, and diversion limit access to cash support among low-income families and push them towards employment. Greater earnings disregards and child care dollars provide positive incentives to work. Regardless of which program mix different states selected, they all pushed recipients into employment more rapidly than the old AFDC program.

\subsection{Changes in other programs, particularly tax programs}

While the changes enacted in 1996 with PRWORA were important, they are only one piece of the policy changes affecting low income families over the 1990s. Several other changes were also highly important.

First, the Earned Income Tax Credit (EITC) was greatly expanded in the early 1990s. The EITC is a refundable tax credit operating through the federal tax system that subsidises low wage workers in low income families. Nonworkers receive no subsidy. Workers in low income families with one child (two or more children) can receive up to USD 2353 (USD 3888) in subsidies as their earnings increase. This provided a substantial increase in the returns to work for families with children and has been linked to increased labour force participation among single mothers (Meyer and Rosenbaum, 2001; Ellwood, 2000). ${ }^{4}$

4 For workers out of the labor force or working few hours, the EITC should increase work incentives. For workers in the upper range of EITC eligibility, it may have work disincentives. The National Tax Journal, December 2000, Vol 53(4, part 2), contains a series of articles on the design and effects of the EITC. 
Second, minimum wages rose over the 1990s, from USD 3.35 per hour at the end of 1989 to USD 5.15 by 1997. This left the real minimum wage in 2000 10.8 percent above its level in 1989. There appear to have been relatively few unemployment effects from these minimum wage changes (Bernstein and Schmitt, 1998).

The combination of a higher minimum wage and an expanded EITC meant that the lowest wage workers (among low income families with children) substantially increased their employment returns. A single mother working fulltime at the minimum wage in 1989 received a total of USD 10,568 (in 2000 dollars) from wages combined with the EITC. The same woman working full time at the minimum wage in 2000 received USD 12,653 if she had one child and USD 14,188 if she had two children.

Third, there were expansions in child care assistance, even beyond the increased TANF dollars states put into child care subsidies. The Child Care and Development Block Grant grew rapidly, providing additional dollars to the states to subsidise child care among low-income families. As a result, child care dollars available to low income families from all sources increased from under USD 2 billion in 1992 to almost USD 10 billion in 2000 (Gish, 2002, Figure 3).

Fourth, while the U.S. continues to lag European countries in the availability of health insurance to low income families, there were significant expansions in the availability of health insurance over the 1990s. All low-income children were eligible for the public health insurance program, Medicaid, by 1999. Women who left welfare were able to continue their Medicaid access for several years in many states. And at least a few states began to experiment to state-subsidised health insurance schemes for low-wage workers who did not receive health insurance through their employers.

\subsection{What effects did these changes have?}

The nature of support available to low income families within the United States changed dramatically over this past decade. The system evolved to provide substantial support for working low income families, with much reduced support for non-workers. Federal dollars available to support working low income families increased from USD 11 billion in 1988 to USD 66.7 billion in 1999 (Blank and Ellwood, 2002). Dollars paid in cash welfare support for (largely nonworking) families headed by non-elderly, non-disabled adults fell from USD 24 billion in 1988 to USD 13 billion by 1999 (all numbers in 2000 dollars.) Cash assistance became far less available, welfare recipients were pushed to find employment, the returns to low wage work rose, and the avail- 
ability of work supports (child care and health insurance) increased to low income families.

Not unimportant, these changes took place at the same time as a major economic boom. The U.S. unemployment rate remained at or below 5 percent through much of the late 1990s. Wages among less skilled workers started to rise in 1995, for the first time since the late 1970s (Blank and Schmidt, 2001). This meant that the macroeconomy reinforced and supported the legislative changes over the 1990s.

As Figure 1 demonstrates, caseloads - the number of families receiving AFDC/TANF assistance - plummeted over the 1990s, continuing to fall through 2001. By the early 2000s, TANF caseloads were about 40 percent of AFDC caseloads only six years earlier. While the 1996 legislation influenced this decline, it was clearly not the only cause, as these caseload declines began two years before PRWORA was enacted.

\section{Figure 1}

\section{Total AFDC/TANF caseloads}

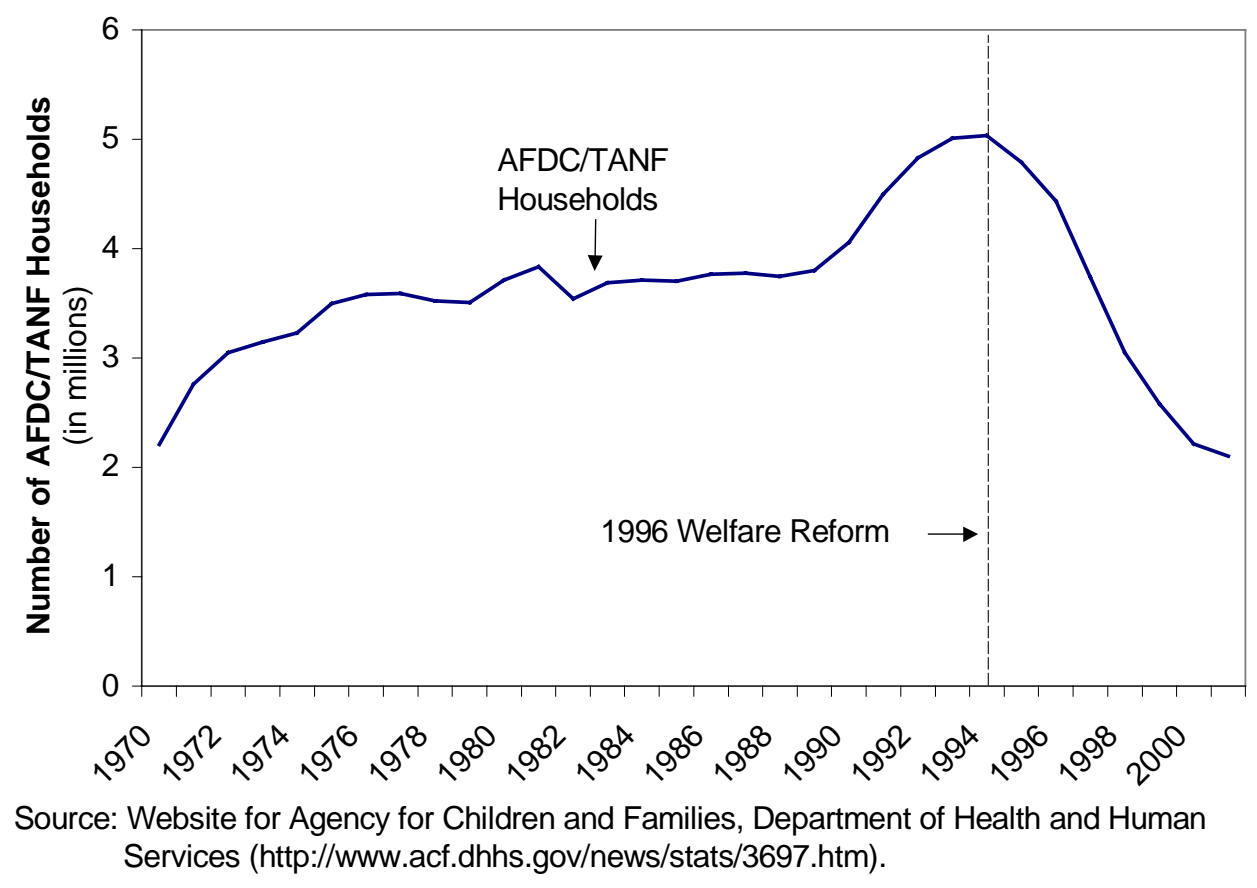

At the same time, work among single mothers soared. Figure 2 shows labour force participation changes among four groups of women between 1989 and 2001. Single women without children worked at a high rate throughout this decade. Married women - with and without children - continued a long-term trend toward increased labour force participation. If anything, this trend less- 
ened slightly in the late 1990s. But single women with children - after almost two decades of stagnant labour force participation rates - experienced a 10 percentage point increase in labour force participation.

This increase was strongly driven by changes in labour force participation among very low-income women. Figure 3 shows the rate of labour market involvement in March of each year among those women who report receiving public assistance in the previous year. In 1989 only 31 percent of 1988's welfare recipients were working. In 2000, 57 percent of 1999's welfare recipients were at work. ${ }^{5}$ In March 2001 the share of welfare recipients from 2000 who reported themselves working fell almost 10 percentage points. This reflects the much smaller caseload decline between 2000 and 2001, as well as the slower labor market among those who did leave public assistance.

\section{Figure 2}

\section{Labor force participation rates for women} by marital status and presence of children, 1989-2001

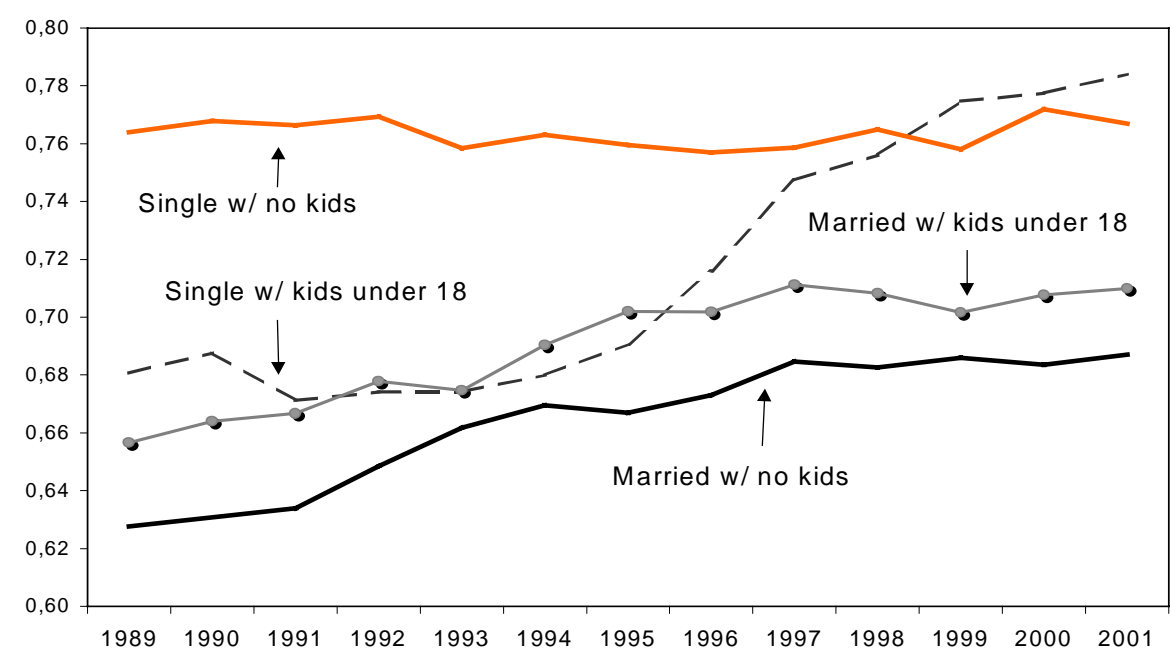

Source: Authors' tabulations of March Current Population Survey data, for women aged 20-65.

Falling caseloads and rising labour force involvement also occurred simultaneously with overall declines in poverty. Among single parents, poverty fell to an historically low rate of 24.7 percent in 2000. The declines in poverty were not nearly as large as the declines in welfare usage, however, resulting in a rising

5 Those not at work in the current year include persons who remain on welfare as well as those who leave welfare but do not find work. See Loprest (2001) or Cancian et al. (1999) for a discussion of how welfare leavers fare; about one-third of welfare leavers are not employed at a future survey date. 
share of workers and working families among the poor. Most analysts who have looked at overall income changes among single mothers over the 1990s conclude that incomes rose somewhat (not by large amounts) among most women (Haskins, 2001; Jencks, Swingle and Winship, 2001). There is some evidence of small income declines among a small share of the most disadvantaged, perhaps consistent with the expected effects of time limits and sanctions. Our understanding of the full impact of these policy changes on the overall well-being of the low-income population remains quite limited, however. We have inadequate measures of the changes in work expenses, in work time versus time with children, or in housing and family situations.

\section{Figure 3}

Labor force participation rate in March among single mothers who received public assistance during the previous year, 1980-2001

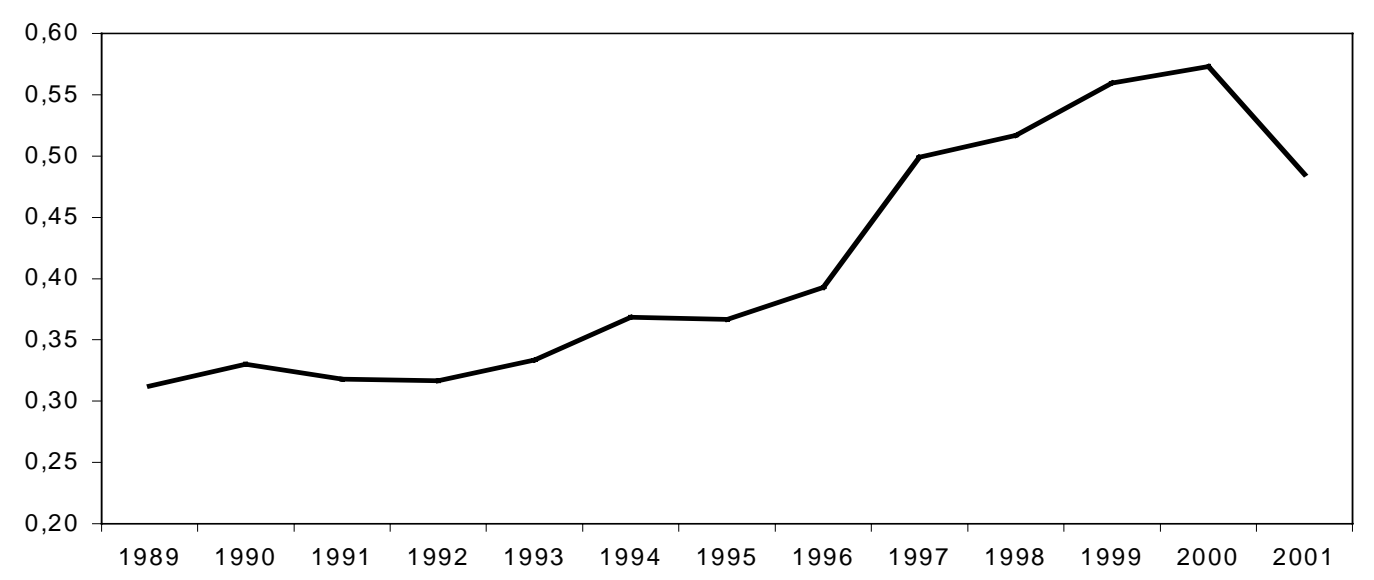

Source: Authors' tabulations of March Current Population Survey Data. Includes all women aged 20-65 who report receiving public assistance in previous year.

A key question of interest has been how much of the changes in caseloads and employment were due to policy change versus a strong economy. In a review of the literature (Blank, 2002), I discuss the real difficulties of doing this analysis in a credible way. The strong labour markets and the policy changes interacted in a variety of ways that make separating their impacts difficult. Most studies, however, suggest that both policy changes and economic changes were important over the 1990s. Neither of them, alone or together, fully explains the magnitude of change, however. There seems to have been a behavioural shift in the willingness of the low-income population to both enter and leave public assistance over this time period. ${ }^{6}$

6 Other reviews of this literature include Grogger, Karoly and Klerman (2002) or Moffitt (forthcoming.) 
Rebecca M. Blank

\section{Lessons for Europe from these reforms}

A growing number of authors (including myself) have written papers describing the "lessons" of U.S. welfare reform for European observers. ${ }^{7}$ Hence some obvious lessons have been already much discussed and I list them here only for completeness.

\subsection{Well-recognized lessons}

1. Economic expansion is a wonderful thing. It's very useful to have a strong macroeconomy if you want to implement work-oriented welfare reform. Economic growth remains the best way to stimulate job creation for low-wage workers. The U.S. was able to move as far and as fast as it did on welfare reform in the late 1990s in part because job availability was never an issue. Reasons behind the strength of the U.S. economy over the recent past decades have been much discussed in U.S./European contexts, with an ongoing debate about effective policies to alleviate high and persistent unemployment rates in many European countries. Changes in the behaviour of U.S. welfare recipients over the late 1990s provides only one of many possible examples demonstrating the value of long-term economic expansion and job growth.

2. The EITC wage subsidy is an innovative and effective program. The EITC is probably the most discussed U.S. policy innovation. The idea of workconditioned benefits has spread, particularly among English-speaking countries. ${ }^{8}$ The EITC design has several advantages over alternative wage subsidy schemes. First, because it is tied into the tax system it can be limited to low wage workers in low income families, rather than being paid out to all low wage workers. This makes it a much more efficient anti-poverty tool than something like a minimum wage. Second, because it is paid only to workers (and employers are often uninformed about which workers get it and which do not) it should have few displacement effects or wage effects. Third, for the same reason, it should not have the "stigmatising" effect that some worker subsidies appear to have created. ${ }^{9}$ Research on the effects of the EITC (cited

7 For instance, see Blank (2001), Haveman and Wolfe (2000), or Ochel (2001b).

8 Ochel (2001a) notes that Australia, England, Ireland, Canada, Finland, France, New Zealand, and the United States all currently have some employment-conditioned benefits.

9 There are, of course, some disadvantages to the EITC design as well. Most notably, being tied to the tax system means that it is largely paid out as a lump sum at the end of the year. While the evidence suggests many workers actually like this as a form of "forced savings" it does limit the availability of EITC subsidies to pay ongoing monthly expenses. Dickert-Conlin and Holtz-Eakin (2000) present models of the potential impact of various wage subsidy schemes. 
above) indicates that it has been important in increasing labour supply among less skilled women with children.

3. Welfare-to-work efforts can be effective. The U.S. has been a leader in pushing work requirements among public assistance recipients. States experimented with welfare-to-work programs throughout the 1980s and the 1990s in the United States, and many of these experiments were evaluated with highly credible randomised evaluations. The result is a substantial body of evidence on the effectiveness of welfare-to-work programs in reducing welfare usage and public costs, and increasing labour supply. ${ }^{10}$ This evidence has been particularly important in the U.S. in persuading people across the political spectrum that these programs can work effectively. Combined with the recent success of the U.S. in reducing caseloads and increasing employment among exrecipients, these studies are drawing increasing European interest.

\subsection{What else have we learned?}

These three lessons have been highlighted in a variety of existing discussions of U.S./European welfare issues. I want to focus the remainder of this section on the question "Six years into the U.S. experiment with welfare reform, what else have we learned?" Some of the additional "lessons" listed below have emerged more clearly in recent years as we gather additional evidence on the results of the U.S. reform efforts. I would argue that there are four additional areas where the results of U.S. welfare reform efforts may be relevant to the policy concerns of at least some European nations.

1. Positive and negative incentives together are better than either alone. One of the most controversial aspect of the U.S. program changes are the negative incentives - time limits, sanctions, and diversion - that are built into their structure. These are punitive measures; they leave some families with a much lower level of benefits or no benefits at all. Although some predicted that caseworkers would not be willing to actually impose sanctions or other benefit limitations on many families, the U.S. evidence suggests that all states are enforcing sanctions. Time limits are still a bit early to assess; only in late 2001 and early 2002 did the first group of women who were continuously on welfare since TANF was enacted begin to hit the 60-month time limit set in many states. At present, we simply lack data on the long-term effects of time limits. Several states had shorter time limit clocks or experimented with time limits

10 See Gueron and Pauly (1991) for a summary of much of the earlier rsearch and Bloom and Michalopoulos (2001) for a summary of much of the key 1990s research. 
prior to the 1996 legislation, so there is some limited evidence on their impacts. $^{11}$

All of these policies essentially limit the entitlement to cash public assistance, either enforcing behavioural requirements (such as work search) or limiting the availability of cash assistance. As Besley and Coate (1992) point out, linking such requirements with public assistance payments can help deter welfare participation among those who could find a job on their own. ${ }^{12}$

These negative incentives produce real behavioural responses. For instance, Grogger (forthcoming) indicates that time limits force mothers with younger children to leave welfare faster. The majority of evaluations of mandatory welfare-to-work programs show significant increases in labour supply and reductions in welfare usage (Bloom and Michalopolous, 2001). The biggest drawback with these programs, however, appears to be that they show very few income effects. In most cases, the increase in earnings is almost entirely offset by the decline in benefits.

Interestingly, positive work incentives - by which I primarily mean higher earnings disregards - have historically shown little positive effect on labour supply, even though economic theory would predict that higher disregards mean more retained wages at low levels of work and should encourage labour supply. Moffitt (1992) notes the remarkable inelasticity of response to changes in the earnings disregard in historical studies of U.S. welfare. This result remains puzzling for economists, although it may reflect recipient's inadequate understanding of how earnings disregards operate.

A credible national study of the effect of recent changes in earnings disregards across the states is not yet available. The most interesting state-specific study, however, is the study of the Minnesota Family Investment Program (MFIP). MFIP was implemented in 1994 and provided a strong earnings disregard, allowing women to receive some cash assistance until their earnings reached about 140 percent of the U.S. poverty line. It also required participation in mandatory job search programs. A randomly assigned control group remained in AFDC without work requirements or substantial earnings disregards. Hence, MFIP involved both strong negative and positive work incentives. A subset of the treatment group (also randomly assigned) was provided with the earnings disregards but not the mandatory work requirements. The results allow the

11 Pavetti and Bloom (2001) and Bloom and Michalopolous (2001) summarize existing evidence on the impact of time limits.

12 Shroyen and Torsvik (2002) also discuss the role of such program mandates. 
separate and joint effects of mandatory job search and earnings disregards to be explored. ${ }^{13}$

The results are shown in Table 1. When only positive work incentives are provided through an expanded earnings disregard, this has little effect on labor supply, consistent with earlier results. But the additional income provided by these disregards had strong income-increasing and poverty-reducing effects. Once mandatory work requirements are added to the program, then labor supply increases as well, but there is little further effect on income or poverty. In other words, the "stick" of mandatory work requirements increases labor supply, but by itself this has little effect on overall income as increases in earnings are offset by reduced benefits. But the "carrot" of greater earnings disregards provides an income enhancing effect. When used together, one gets the best possible result: increased work and earnings, along with reduced poverty.

\section{Table 1}

Effects of incentive schemes within the Minnesota Family Investment Program (MFIP)

Results three years after randomised treatment begins

\begin{tabular}{|l|c|c|}
\hline & \multicolumn{2}{|c|}{$\begin{array}{c}\text { Difference in treatment group versus } \\
\text { control group }\end{array}$} \\
\hline & $\begin{array}{c}\text { High earning disre- } \\
\text { gards } \\
\text { only }\end{array}$ & $\begin{array}{c}\text { Full MFIP: earnings } \\
\text { disregards plus manda- } \\
\text { tory employment }\end{array}$ \\
\hline Employment (\%) & $3.6^{*}$ & $11.5^{* * *}$ \\
\hline Annual Earnings (USD) & -191 & $571^{*}$ \\
\hline Annual Cash Transfers (USD) & $1,165^{* * *}$ & $614^{* * *}$ \\
\hline Annual Income (USD) & $973^{* * *}$ & $1,185^{* * *}$ \\
\hline Poverty (\%) & $-8.3^{* * *}$ & $-12.4^{* * *}$ \\
\hline $\begin{array}{l}\text { The controls were participants in the AFDC program in Minnesota. } \\
* \text { Significant at the 10\% level; *** Significant at the 1\% level. }\end{array}$ \\
\hline
\end{tabular}

Source: Bloom and Michalopolous (2001, Appendix Tables C.2 and C.3). Poverty data comes from Miller et al. (2000, Table 4.5).

13 For more detailed description of the MFIP program, see Miller et al. (2002). 
Other programs have shown similar effects. For instance, the Self Sufficiency Project (SSP) in Canada provided large benefit increases to recipients willing to accept a mandatory requirement that participants must work 30 weeks or more. Also evaluated by a random assignment methodology, SSP shows equally promising results with strong labour supply increases along with real poverty reductions. ${ }^{14}$

I believe the lesson of these results is first, that relatively strong measures to mandate work participation can be effective in accomplishing that. Indeed, the available evidence to date suggests that work mandates (with strong sanctions for non-co-operation) are more effective at inducing work than are positive wage incentives. But the second lesson is just as important. Strict work requirements by themselves may have little income-enhancing effects if they are not combined with some form of wage support for low-skilled welfare recipients. Low earnings disregards are one way to provide this, although other types of subsidies to low wage workers may be effective as well. European policymakers who want to consider getting tougher with work requirements, would do well to look at these U.S.-based lessons about program design.

2. Job training is not superior to work experience. Another result that is emerging from the evaluations of U.S. welfare reform efforts over time is the fact that education and training programs do not seem any more effective in promoting long term labour force attachment and increased earnings than do work experience programs. In various welfare reform experiments in the U.S. during the early 1990s, states tested training programs - so called "human capital development" (HCD) programs - against "work first" programs - socalled "labour force attachment" (LFA) programs. Several sites (Atlanta, GA; Grand Rapids, MI; and Riverside County, CA) ran both programs in the same location, randomly assigning people to each. Other places chose one or the other and evaluated them against traditional AFDC programs. Several programs selected somewhat mixed models, including work-first efforts for some recipients and education and training for others. All of these sites were evaluated with randomised experiments, making the results particularly credible. ${ }^{15}$

While labour economists are likely to predict that education and training will make people better off in the long run, these evaluations challenge that assessment. Work-first LFA programs increased earnings and decreased welfare usage more quickly, while HCD programs cost more, particularly in the first year when women were training rather than working. But even three years out,

14 For more detail on SSP, see Michalopoulos et al. (2000). Blank (2002) provides more detailed comparisons between SSP, MFIP, and other related programs.

15 For more detailed summaries, see Bloom and Michalopolous (2001) and Michalopolous and Schwartz (2001). 
after women from HCD programs had been in the labour market two years, HCD participants did not outperform LFA participants. This may suggest that the gains to experience among women who have been out of the labour market may be larger than the gains to education and training, at least initially. It is particularly interesting that employment outcomes did not seem significantly worse among less skilled participants or participants with identifiable barriers to work, such as child care or health problems. While these groups had lower labor force participation in general, their relative gains from work-first programs were as large as those of more advantaged women.

Of course, experience and education are both forms of human capital. Other work (Gladden and Taber, 2000) has indicated that even low wage labour force participants do receive wage increases over time with experience. But it is troubling that the education programs by themselves did not appear to produce much in the way of wage gains; the primary gains that occurred to women in these programs came when they entered the work force and acquired experience. For instance, while the education programs significantly increased the number of participants holding a high school equivalency degree, there was little evidence that this resulted in higher earnings or more work hours.

As it turns out, the over-time gains in labour force involvement and earnings are greatest in the "mixed" programs that assign some women to work-first and other women to training. This immediately raises the question of who among the participants should be assigned to work first as opposed to training programs - a question for which we have few good answers. But it also suggests that simply following a work-first strategy or a job training strategy for all participants may not be the most effective approach.

The lesson from this research is that work-first programs may be the right approach for some share of welfare participants. Many work-related efforts within public assistance programs in European nations have included a strong dose of education and training. While this may be appropriate for some participants, training programs cost more and their additional costs may not be necessary in order to successfully increase work and earnings among at least some public assistance recipients who have little recent job experience. Since the U.S. has moved almost entirely to a work-first model, perhaps the correct lesson to be stated here is that the U.S. should integrate more job training and education into its work programs, while European labour force programs should pay more attention to work experience rather than training.

3. Finding a job is just one piece of moving single mothers into work. Much of the policy discussion around welfare reform in the U.S. prior to the passage of PRWORA in 1996 focused solely on jobs: how to help women locate and hold jobs. It is clear that this is an important component of any work-oriented public 
assistance program. But particularly for the single mothers who often participate heavily in public assistance, other concerns might be just as important in helping women transition into long-term employment.

Child care is probably the most important element in addition to jobs. States in the U.S. have increased their child care subsidy dollars every year since the 1996 welfare reform, discovering that the need to help women find and fund child care may be as important as the need to assist them in job search. Many examples of failed transitions into work are based on situations where jobs require non-standard hours (when child care is hard to locate) or where unstable and unreliable child care leads mothers lose or leave their jobs.

Access to health care is also important, particular for those women and children with ongoing health problems. We have less evidence on the precise role that loss of health insurance plays in women's difficulties in job holding, but anecdotal evidence suggests this can be important.

Hence, a key "lesson" from the U.S. is that job availability is NOT the only requirement for a successful transition to work. European nations that provide substantial support to working mothers (such as Sweden) are in a better situation than the U.S. to deal effectively with job-holding problems that relate to the availability of child care and/or health care. Even if some of these nations may face more difficulties in helping women locate jobs, they have an advantage in having other work supports already in place. Hence, they may be able to concentrate more of their program resources on the job creation and location issue, while in the U.S. more program resources have had to go into other work supports. European nations that provide little support to working mothers (such as Germany) need to worry about this lack of support if they want to provide more work incentives within social assistance programs.

Both the U.S. and Europe, however, need to be more aware of the barriers to work faced by some public assistance recipients. U.S. research suggests that between one-quarter and one-third of the caseload may face multiple barriers to work, including physical or mental health problems that limit their work capacity, substance abuse problems, issues around domestic violence, very low skills, English-language problems, or child health problems. ${ }^{16}$ Welfare recipients with depression problems are emerging in a number of studies as a particularly vulnerable and difficult-to-assist group. Danziger (2001) indicates that one-third of current and recent recipients meet the criteria for at least one

16 Zedlewski and Loprest (2001) indicate 26 percent of TANF leavers have two or more barriers to work. Danziger et. al. (2000) - with a much more expansive measure of barriers - indicate that one third face three or more barriers to work. 
of six major psychiatric disorders. ${ }^{17}$ Experimental programs in the U.S. indicate that working with these more disadvantaged populations requires more resources, more time, and more personal attention for these women to become truly "work ready".

On the other hand, there is growing evidence that a substantial number of these women can work at least part time. Employment rates among women with multiple work barriers are NOT zero. Danziger et al. (2000) indicate that women with two to three barriers have a 62 percent probability of working at least 20 hours; women with four to six barriers have a 40 percent probability of work. Differently designed welfare-to-work programs and more phased-in employment requirements may make sense for this population.

The difficult issues raised by these programs are three fold, and the U.S. has yet to find effective solutions to any of them: First, there is a need to identify persons with these difficulties at an early stage and direct them into alternative programs. A worst-case scenario might occur when these women are treated like all others, fail to respond fully to work requirements, and are sanctioned off public assistance without hope of any future support. Second, efforts to assist these populations are expensive and require a greater budgetary commitment. This is made more difficult by the fact that some highly disadvantaged persons may not be very "politically" sympathetic, that is, they may be substance abusers or their mental health problems may make them very difficult to work with. Third, we still know too little about what programs will help women who face real barriers to employment. It is simply difficult to treat substance abuse, to reduce domestic violence, or to help workers cope with depression or lifelong learning disabilities.

Research on the U.S. welfare reform efforts has clearly identified these groups as special problems. Both U.S. and European public assistance efforts need to do a better job of finding ways to cope with these more disadvantaged public assistance recipients.

4. Behavioural patterns can be changed. Those who supported U.S. welfare reform in the mid-1990s argued that we needed to change the "culture" of welfare, that is, to change the set of expectations about appropriate behaviour. In the U.S., this meant not only giving women an expectation that long-term welfare receipt was neither available nor desirable, but also changing expectations around marriage and non-marital childbearing.

There is a growing body of evidence that the U.S. has been at least partially successful doing just this. The evidence is of two sorts. First, there was a dis-

17 These include major depression, generalized anxiety disorder, social phobia, panic attacks, alcohol dependence or drug dependence. 
continuous change in behaviour away from welfare receipt somewhere around the mid-1990s. Even the most detailed models of caseloads have large unexplained negative declines in the late 1990s when welfare usage declined far more than anyone expected. In some ways this was a mirror of the late 1960s, when welfare usage soared far beyond what any change in program parameters would have predicted. Moffitt (1992) indicates the 1960s increase was due to an increase in take-up rates among the eligible population.

We have only limited evidence on take-up of welfare among the eligible population over the late 1990s. With 50 highly-diverse state programs it is extremely difficult to estimate eligibility in national data sets. There is clear evidence that take-up of two welfare-related programs (Food Stamps and Medicaid) appears to have dropped (Greenstein and Guyer, 2001). Given the ongoing public attention to "getting tough" with welfare and the implementation of mandatory work requirements and time limits, it would not be surprising if a number of potentially eligible recipients were choosing to avoid welfare or to leave it as soon as possible. (In fact, time limits encourage eligible persons who have other forms of support to use them instead rather than using up ones' lifetime limit of welfare.) All of this suggests that the U.S. welfare-towork reform effort has been successful at discouraging participation among some set of eligibles who have other options.

The second piece of evidence for widespread behaviour changes is the research that suggests welfare reform is affecting family formation and fertility. This evidence is still scattered, and indeed, one would not expect to see rapid changes in these demographic indicators. But a growing number of studies indicate that cohabitation has increased and nonmarital fertility has decreased. ${ }^{18}$

The lesson in all of this is that attitudes and expectations can be changed. We have few models within economics to help us understand and track this process, but it appears that fewer people are willing to enter or stay on welfare and these changes are greater than the marginal changes in program parameters might predict. This is consistent with arguments that preferences around work ethics and social norms may be endogenous and can be altered by policy choices (Lindbeck, Nyberg and Weibull, 1999.)

In Europe, where there is substantial concern with "dependency" in a variety of areas - such as disability programs or early retirement as well as public assistance or unemployment insurance - the U.S. experience suggests that significant behavioural revolutions are sometimes possible. Such revolutions

18 For instance, see Horvath-Rose and Peters (2001), Schoeni and Blank (2000), Miller et al. (2000). 
require major program changes, combined with widespread public discussion and attention. While it is too early to tell how permanent these behavioural changes are in the U.S. - much less what the long-term well-being effects of such changes may be - the U.S. evidence indicates that it is possible to dramatically affect the attractiveness and willingness of people to receive public assistance.

\subsection{Caveats to these U.S.-European comparisons}

There are always limits to how applicable one country's policy outcomes are to another country's policy possibilities. In the case of U.S./European comparisons, there are a number of differences. Here I provide a very partial listing of the some of the key issues that might make U.S. welfare policy changes of limited interest to many European nations.

1. Less tolerance for variance. The U.S. reform is fundamentally based on the devolution of welfare program authority from the federal government to the states. While some European countries (like Germany) follow a federalist model, most do not. Widespread acceptance of a system that allows a great deal of local discretion and difference in program design and parameters may be much less in Europe than in the U.S.

2. Less tolerance for strong penalties. The 1996 PRWORA legislation abolished cash welfare as an entitlement to all eligible citizens. This made it possible for states to enforce time limits, sanctions, and other program rules that prevent otherwise-eligible persons from claiming public assistance. Given a very different history of much more generous transfer programs, it is not clear that most European nations would be willing to impose the eligibility limits and benefit cuts imbedded in the U.S. system.

Another way of saying this is that European nations have traditionally focused more on poverty alleviation and less on the behaviour ("welfare dependency") of recipients. Given a greater distaste for poverty and a desire for a more egalitarian income distribution, European nations may find it unpalatable to enforce strong penalties on those who remain on public assistance.

3. A different economic environment and more need for job creation. The U.S. has been particularly fortunate in an economy with widespread job availability over the past decade. Even in the recent economic slowdown unemployment has stayed below 6 percent. In a less job-rich environment, more European countries have to worry about job availability. The design of a work-oriented public assistance system may be less effective (and will certainly be more expensive) if public sector job creation is needed in order to create work slots 
for public assistance recipients. Alternatively, stimulating low-wage job growth may require lowering wages or limiting job protection, which could create a host of political problems.

4. Different populations of concern. U.S. welfare reform efforts have been heavily focused on less-skilled single mothers. While this population may be of interest, many European policymakers are equally concerned about the long-term receipt of public benefits (typically unemployment payments) among younger unemployed persons, as well as receipt of unemployment and disability payments among older workers. Policy lessons based on single mothers may be less applicable to these different populations.

\section{Why are European and U.S. welfare discussions moving closer?}

I close this paper with a few musings on why European interest in U.S. welfare reform efforts is as strong as it is. As noted at the beginning, there is surprisingly strong policy interest in U.S. welfare reform by European policy observers. This is reflected in the growing collection of European-based academic research focusing on potential disincentives and costs of welfare-state programs. ${ }^{19}$ To a U.S. researcher, long used to mild sarcasm from European colleagues about the punitive and limited nature of U.S. public assistance programs, this is quite striking.

Let me suggest at least three possible reasons for converging interests around questions of welfare reform. ${ }^{20}$ First, European nations have been facing more budgetary limits in recent decades. In part, this is due to slower economic growth rates. In part, it is due to demographic changes that are producing an aging population and growing strains on budgets. In part, it is due to the economic effects of monetary union within Europe, which has forced nations to pay closer attention to budget deficits. The effects of a large number of transitioning economies in eastern Europe, following the collapse of the Soviet Union, has also had an impact on many European nations, especially Germany.

It is exactly a tighter budget environment in which concerns about welfare dependency and over-use of public assistance programs might be expected to arise. With tight budgets and growing population demand for assistance, "get tough" policies to reduce welfare rolls become more attractive.

19 For a few recent examples see Riphahn (2000) who discusses take-up rates in German social assistance; Lalive, Ours and Zweimüller (2002) who discuss the effects of benefit sanctions in the Swiss unemployment insurance system; or Gurgand and Margolis (2002) who discuss the relative work disincentives within the French public assistance program (RMI).

Lindbeck (2002) discusses some similar issues. 
The long-term slower macroeconomy has also affected the European conversation around welfare. As more and more analysts have become convinced that European labour markets are too inflexible and over-regulated, this has produced broad-scale interest in ways to introduce more efficiency into the economies. Not surprisingly, concern with disincentive effects of assistance programs are one response.

Second, the emerging economic co-operation within the European Union has produced concern about the response to national social policies if labour becomes more mobile across Europe. While little progress has been made in EU conversations about social policy convergence, there is nervousness about the extent to which more generous programs in some countries will induce migration. The "race to the bottom" - a long-discussed concern in the U.S. - argues welfare benefits will be underprovided if there is a threat of "welfare migration" across states. Each state lowers benefits below what they would prefer in an isolated world to avoid being the most generous state (which would induce in-migration of poor populations.) Within Europe, these concerns include both migration from poorer parts of the EU as well as migration from eastern Europe and the middle east.

Third, racial issues are becoming more prominent in Europe. More than one observer has argued that U.S. "exceptionalism" - lower benefits and greater concern about behaviour among the poor - is due to the racial and ethnic diversity of the U.S. population. New immigrant groups were always poorer in the U.S., and suspicions about each wave of sequential immigrants focused on keeping them from taking too much from native workers, including overusing U.S. welfare benefits. It is not accidental that, following two decades of very high immigration rates in the U.S., the 1996 legislation cut immigrants off from federally-funded public assistance programs.

Perhaps even more important than recent immigrant flows, the problem of race in America and the role of African Americans have deeply affected the public view of welfare. For instance, even though black women have historically been a minority of welfare recipients, public depictions of welfare recipients are disproportionately black. Alesina, Galser and Sacerdote (2001) suggest that race is a primary reason for a more limited system of public support in the U.S.

Europe has become much more diverse in recent decades as well. Tensions around the presence of immigrants have been much discussed, particularly the influence of these tensions on the rise of right-wing politicians. Both the growth in immigrants (non-natives) as well as the fact that many immigrants are also persons of color has led to a growing number of racially-tinged incidents throughout Europe. If indeed it is race and immigration that has led to U.S. "exceptionalism" in social policy, then it is perhaps not surprising that 
European social policy concerns have begun to look more like historical U.S. concerns over the past decade.

\section{Conclusions}

The U.S. welfare reforms are still very much an experiment-in-progress. We are just now finding out how effectively these redesigned and work-oriented programs operate in a slower economy. We are just beginning to observe a number of states enforcing time limits on women. We have only limited data on how working single parents and their children - who in an earlier time might have received welfare - are faring. One might care about the impact of these reforms not just on the adult workers but also on their children and the communities in which these workers live. Any change as dramatic as the U.S. welfare reform will necessarily produce some who benefit and some who lose. The recent strong economy has somewhat masked our ability to analyse these distributional gains and losses in the years immediately after reforms were enacted.

Many of the changes that resulted from welfare reform in the U.S. were clearly shaped by the particular environment in which they occurred. But some of the key lessons from the U.S. - about the value of work incentives (positive and negative), the usefulness of work experience for many public assistance recipients, and the need to pay attention to issues beyond job availability (particularly for single mothers) - may be useful to other countries interested in moving persons from public assistance into work.

Most of all, the U.S. experience is compelling because of it demonstrates a case where dramatic changes occurred in relatively short periods of time. Both welfare programs and behaviour of welfare recipients changed more substantially than any U.S. observer would have predicted in the mid-1990s. This type of systemic change is unusual in the policy world; most change tends to be on the margins. A primary reason for European policy-makers to study U.S. welfare reform is simply to try and understand the conditions under which such systemic change can occur. Whether these conditions can be duplicated in other national environments remains an open question. 


\section{References}

Alesina, A., E. Glaeser and B. Sacerdote (2001), "Why Doesn't the U.S. Have a European-Style Welfare System?", Working Paper 8524, Cambridge MA: National Bureau of Economic Research.

Bernstein, J. and J. Schmitt (1998), Making Work Pay: The Impact of the 1996-97 Minimum Wage Increase, Washington D.C.: Economic Policy Institute.

Besley, T. and S. Coate (1992), "Workfare versus Welfare: Incentive Arguments for Work Requirements in Poverty-Alleviation Programs", American Economic Review 82(1), 249-261.

Blank, R. M. (2001), "What Can Other Countries Learn About Fighting Poverty from U.S. Welfare Reform?", Zeitschrift für Sozialreform 47(4), 464-480.

Blank, R. M. (2002), "Evaluating Welfare Reform in the United States", Journal of Economic Literature 40(4), 1105-1166.

Blank, R. M. and D. T. Ellwood (2002), "The Clinton Legacy for America's Poor", in: J. A. Frankel and P. R. Orszag (eds.), American Economic Policy in the 1990s, Cambridge MA: MIT Press.

Blank, R. M. and L. Schmidt (2001), "Work, Wages, and Welfare", in: R. M. Blank and R. Haskins (eds.), The New World of Welfare, Washington D.C.: Brookings Institution.

Bloom, D. and Ch. Michalopoulos (2001), How Welfare and Work Policies Affect Employment and Income: A Synthesis of Research, New York: Manpower Demonstration Research Corporation.

Cancian, M., R. Haveman, T. Kaplan, D. Meyer and B. Wolfe (1999), "Work, Earnings, and Well-Being After Welfare", in: S. H. Danziger (ed.), Economic Conditions and Welfare Reform, Kalamazoo, MI: W.E. Upjohn Institute for Employment Research.

Danziger, S., M. Corcoran, S. Danziger, C. Heflin, A. Kalil, J. Levin, D. Rosen, K. Seefeldt, K. Siefert and R. Tolman (2000), "Barriers to the Employment of Welfare Recipients", in: R. Cherry and W. M. Rodgers, (eds.), Prosperity for All? The Economic Boom and African Americans, New York: Russell Sage.

Danziger, S. (2001), "Comments on 'TANF and the Most Disadvantaged Families", in: R. M. Blank and R. Haskins (eds.), The New World of Welfare, Washington D.C.: Brookings Institution. 
Dickert-Conlin, S. and D. Holtz-Eakin (2000), "Employee-Based Versus Employer-Based Subsidies to Low-Wage Workers: A Public Finance Perspective”, in: D. Card and R. M. Blank (eds.), Finding Jobs: Work and Welfare Reform, New York: Russell Sage.

Ellwood, D. T. (2000), "The Impact of the Earned Income Tax Credit and Social Policy Reforms on Work, Marriage, and Living Arrangements", National Tax Journal 53(4, part 2), 1063-1105.

Evans, M. (2001), Welfare to Work and the Organisation of Opportunity: Lessons from Abroad, CASEreport 15, ESRC Research Centre for Analysis of Social Exclusion, STICERD, London: London School of Economics.

Feist, H. and R. Schöb (1998), "Workfare in Germany and the Problem of Vertical Fiscal Externalities", FinanzArchiv 55, 461-480.

Gish, M. (2002), Child Care: Funding and Spending under Federal Block Grants, CRS Report to Congress, Washington D.C.: Congressional Research Service.

Gladden, T. and Ch. Taber (2000), "Wage Progression Among Less Skilled Workers", in: D. Card and R. M. Blank (eds.), Finding Jobs: Work and Welfare Reform, New York: Russell Sage Foundation.

Greenstein, R. and J. Guyer (2001), "Medicaid and Food Stamps", in: R. M. Blank and Ron Haskins (eds.), The New World of Welfare, Washington D.C.: Brookings Institution.

Grogger, J. (2003), "The Effect of Time Limits, the EITC, and Other Policy Changes on Welfare Use, Work, and Income Among Female-Headed Families", Review of Economics and Statistics, forthcoming.

Grogger, J., L. Karoly and J. Klerman (2002), Consequences of Welfare Reform: A Research Synthesis, Document DRU-2676-DHHS, prepared by RAND for the Agency for Children and Families, Department of Health and Human Services. Santa Monica: CA, RAND.

Gueron, J. and E. Pauly (1991), From Welfare to Work, New York: Russell Sage.

Gurgand, M. and D. N. Margolis (2002), "Welfare and Labor Earnings; An Evaluation of the Financial Gains to Work", Discussion Paper No. 461, Bonn: IZA.

Haskins, R. (2001), “The Second Most Important Issue: Effects of Welfare Reform on Family Income and Poverty", in: R. M. Blank and R. Haskins (eds.), The New World of Welfare, Washington D.C.: Brookings Institution. 
Haveman, R. and B. Wolfe , (2000), "Welfare to Work in the U.S.: A Model for Other Developed Nations?", International Tax and Public Finance 7(1), 95-114.

Horvath-Rose, A. and H. E. Peters (2001), "Welfare Waivers and Non-Marital Childbearing", in: G. J. Duncan and P. L. Chase-Lansdale (eds.), For Better and For Worse: Welfare Reform and the Well-Being of Children and Families, New York: Russell Sage.

Jencks, Ch., J. Swingle and S. Winship (2001), Did Welfare Reform Alter Single Mothers' Income, Living Arrangements or Ability to Feed Their Families?, unpublished manuscript.

Lalive, R., J. C. van Ours and J. Zweimüller (2002), "The Effect of Benefit Sanctions on the Duration of Unemployment", Discussion Paper No. 3311, London: Center for Economic Policy Research.

Lindbeck, A. (2002), "Changing Tides for the Welfare State", CESifo Working Paper No. 645(3), Munich: Center for Economic Studies and Ifo Institute for Economic Research.

Lindbeck, A., S. Nyberg and J. W. Weibull (1999), "Social Norms and Economic Incentives", Quarterly Journal of Economics 114(1), 1-35.

Loprest, P. (2001), "How are Families that Left Welfare Doing? A Comparison of Early and Recent Welfare Leavers" Series B, No B-36, Assessing the New Federalism Project, Washington D.C.: Urban Institute.

Meyer, B. D. and D. T. Rosenbaum (2001), "Welfare, The Earned Income Tax Credit, and the Labor Supply of Single Mothers", Quarterly Journal of Economics 116(3), 1063-1114.

Michalopoulos, Ch. and Ch. Schwartz (with Diana Adams-Ciardullo, 2001), What Works Best for Whom: Impacts of 20 Welfare-to-Work Programs by Subgroup, National Evaluation of Welfare-to-Work Strategies, Washington D.C.: U.S.DHHS and U.S. Department of Education.

Michalopoulos, Ch., D. Card, L. A. Gennetian, K. Harknett and Ph. K. Robins (2000), The Self-Sufficiency Project at 36 Months: Effects of a Financial Work Incentive on Employment and Income, Ottawa, Canada, Social Research and Demonstration Corporation.

Miller, C., V. Knox, L. A. Gennetian, M. Dodoo, J. A. Hunter and C. Redcross (2000), Reforming Welfare and Rewarding Work: Final Report on the Minnesota Family Investment Program, 1, Effects on Adults, New York: MDRC. 
Moffitt, R. A. (1992), "Incentive Effects of the U.S. Welfare System: A Review", Journal of Economic Literature 30(1), 1-61.

Moffitt, R. A. (2003), “The Temporary Assistance for Needy Families Program", in: R. Moffitt, (ed.), In Means Tested Transfer Programs in the United States, Chicago: University of Chicago Press, forthcoming.

Ochel, W. (2001a), "Financial Incentives to Work - Conceptions and Results in Great Britain, Ireland, and Canada", CESifo Working Paper No. 537, Munich: Center for Economic Studies and Ifo Institute for Economic Research.

Ochel, W. (2001b), "Welfare to Work in the U.S.: A Model for Germany?", CESifo Working Paper No. 537, Munich: Center for Economic Studies and Ifo Institute for Economic Research.

Pavetti, La. and D. Bloom (2001), "Sanctions and Time Limits: State Policies, Their Implementation and Outcomes for Families", in: R. M. Blank and R. Haskins (eds.), The New World of Welfare, Washington D.C.: Brookings Press.

Riphahn, R. (2000), "Rational Poverty or Poor Rationality? The Take-up of Social Assistance Benefits", Discussion Paper No. 124, Bonn: IZA.

Schoeni, R. F. and R. M. Blank (2000), "What Has Welfare Reform Accomplished? Impacts on Welfare Participation, Employment, Income, Poverty, and Family Structure", National Bureau of Economic Research Working Paper 7627, Cambridge: MA: NBER.

Schroyen, F. and G. Torsvike, (2002), "Sticks and Carrots for the Alleviation of Long Term Poverty”, CESifo Working Paper No. 659 (3), Munich: Center for Economic Studies and Ifo Institute for Economic Research.

U.S. Department of Health and H. Services (DHHS) (2000), Temporary Assistance for Needy Families (TANF) Program, Third Annual Report to Congress, Washington D.C.: DHHS.

Weil, A. (2002), "Ten Things Everyone Should Know About Welfare Reform", New Federalism Report, Series A, No. A-52, Washington D.C.: Urban Institute.

Zedlewski, S. R. and P. Loprest (2001), "Will TANF Work for the Most Disadvantaged Families?", in: R. M. Blank and R. Haskins (eds.), The New World of Welfare, Washington D.C.: Brookings Institution. 